\title{
Insomnia and the level of stress among students in Krakow, Poland
}

\author{
Insônia e nível de estresse em estudantes de Cracóvia, Polônia
}

\author{
Anna Średniawa, (1D Dominika Drwiła, Anna Krotos, Damian Wojtaś, Natalia Kostecka, Tomasz Tomasik
}

\begin{abstract}
Introduction: Stress and insomnia are increasing problems in young people in highly developed countries. They influence both the physical and psychological aspects of life and seem to be related to each other. Various strategies to cope with stress exist and can be used to reduce its level. The main goal of our study was to find a relationship between insomnia, stress, stresscoping strategies and selected social and medical factors among students.

Methods: A cross-sectional study was conducted in March 2017 among students of seven public Krakow universities, using the Perceived Stress Scale 10, an abbreviated version of the Coping Orientation to Problems Experienced inventory (mini-COPE inventory) and the Athens Insomnia Scale. In the statistical analysis, the chi-square, Student's $t$ test and Spearman's rank correlation coefficient were used.

Results: A total of 264 students aged $22.22 \pm 1.5$ years were involved in the study. High stress levels occurred in $10 \%$ of the respondents. A statistically higher level of stress was revealed in people suffering from chronic diseases $(p=0.006)$ and in cigarette smokers $(p=0.004)$. The most common stress-coping strategies were active coping and planning. Insomnia was present in $19.7 \%$ of the students. Insomnia level was correlated with the intensity of perceived stress $(p=0.00 ; r=0.44)$.

Conclusions: According to our study, one tenth of Krakow students perceive a high level of stress, and one fifth of the respondents suffer from insomnia. There is a strong positive correlation between level of insomnia and level of stress. To ensure high quality of life, problems such as stress and insomnia should be taken into consideration by every general practitioner. Keywords: Insomnia, stress, coping strategies, students, Poland.
\end{abstract}

\section{Resumo}

Introdução: Estresse e insônia são problemas cada vez mais presentes em pessoas jovens em países altamente desenvolvidos. Eles influenciam tanto os aspectos físicos quanto os psicológicos da vida e parecem estar relacionados entre si. Várias estratégias de enfrentamento (coping) do estresse existem e podem ser usadas para reduzir seu nível. O objetivo principal deste estudo foi investigar a relação entre insônia, estresse, estratégias de coping, e certos fatores sociais e médicos em estudantes.

Métodos: Um estudo transversal foi conduzido em março de 2017 com estudantes de sete universidades públicas da Cracóvia, na Polônia, utilizando a Escala de Estresse Percebido 10, uma versão abreviada do Inventário para Medir Estratégias de Enfrentamento de Estresse (mini-COPE) e a Athens Insomnia Scale. Na análise estatística, foram utilizados os testes qui-quadrado, $t$ de Student e o coeficiente de correlação de Spearman.

Resultados: Um total de 264 estudantes com idade média de $22,22 \pm 1,5$ anos foram incluídos no estudo. Altos níveis de estresse ocorreram em $10 \%$ dos respondentes. Um nível estatisticamente mais alto de estresse foi revelado em pessoas sofrendo de doenças crônicas $(p=0,006)$ e em fumantes $(p=0,004)$. As estratégias de coping mais comuns foram coping ativo e planejamento. A insônia esteve presente em $19,7 \%$ dos alunos. O nível de insônia se correlacionou com a intensidade do estresse percebido $(p=0,00 ; r=0,44)$.

Conclusões: De acordo com este estudo, um décimo dos estudantes de Cracóvia percebe um alto nível de estresse, e um quinto dos respondentes sofrem de insônia. Há uma forte correlação positiva entre nível de insônia e nível de estresse. Para garantir alta qualidade de vida, problemas como estresse e insônia devem ser levados em consideração pelo médico generalista.

Descritores: Insônia, stress, estratégias de coping, estudantes, Polônia. 


\section{Introduction}

Stress, from a psychological perspective, is defined as "an imbalance or a potential imbalance between someone's requirements and the ability to meet them". ${ }^{1}$ This growing problem affects more and more people in many highly developed countries, resulting from lifestyle and social conditions. ${ }^{2}$

Little is known about the prevalence of stress in the student population. The level of stress differs, depending on the study population and other factors connected with lifestyle. A study performed in recent years in Poland at the Medical University, Nicholas Copernicus University and Collegium Medicum showed that $23 \%$ of the students felt stress almost every day. The prevalence of stress was higher among third year students than among respondents in their final year. ${ }^{3}$

Stress has a negative influence on every aspect of human life: physical, psychological and social. Acute stress, especially traumatic episodes, is considered to be dangerous, but chronic stress is also potentially harmful. Children and young people are particularly susceptible to this phenomenon. Acute or chronic stress causes numerous syndromes, including sleep disorders, stress-related depression, traumatic stress, chronic fatigue syndrome and others, reducing life expectancy and decreasing the quality of life. ${ }^{4}$

The concept of "coping with stress" can be defined as the effort taken to deal with a person's duties that are assessed as being too great or overwhelming in their opinion. Many mechanisms of coping with stress have been described, but all of them derive from two primary strategies - task-oriented (a problem-oriented strategy) and self-regulation of emotions. ${ }^{1}$ The skill of coping with stress influences quality of life and mental well-being. ${ }^{5,6}$

Insomnia, an insufficient amount of sleep or unsatisfying quality of sleep, is often associated with stress. It impairs function in many areas of life. According to various studies, this problem may affect as many as $53 \%$ of patients visiting a general practitioner. ${ }^{7}$ It is observed not only in older people: schoolchildren and infants may also have sleep disorders. ${ }^{8}$ The most common causes of insomnia are assumed to be mental disorders (35\%). Data from 2,413 people aged 1879 years showed that, in Poland, $60 \%$ of respondents had difficulties in falling asleep and $45 \%$ in sleep maintenance. Premature awakening in the morning was experienced by $26 \%$ of the respondents. ${ }^{9}$ Results from the same study showed that in the younger population, aged 18-39 years, subjective insomnia was reported by $44.3 \%$ of women and $32.1 \%$ of men. To the best of the authors' knowledge, no recently published data about insomnia among students in Poland are available.
Because correlations between level of stress, stressmanagement strategies and insomnia among young people in Poland have not been sufficiently studied so far, the main goal of our study was to find a relationship between these factors in a group of students in Krakow. In particular, the connections between selected social and health factors (chronic disease, use of stimulants, physical activity, etc.) and level of stress, stress-coping strategies and level of insomnia were assessed.

\section{Methods}

\section{Design}

A cross-sectional questionnaire study was conducted in Krakow, Poland, among students from seven local universities.

\section{Setting}

Krakow is the second largest and one of the oldest cities in Poland, situated on the Vistula River in the south of Lesser Poland. There are seven public universities in Krakow, and the study was performed in all of them. From each of the six large universities (those that offer more than 10 undergraduate courses) such as the Jagiellonian University, University of Technology, University of Science and Technology, University of Economics, Pedagogical University of Krakow and the University of Agriculture, two courses were randomly selected. From the University of Physical Education, which is a small institution offering four undergraduate courses, one course was randomly selected.

\section{Population studied}

In each undergraduate course, we randomly selected a group of third-year students who took part in the study. Third-year students were chosen because they were in the middle of university education. In this way, we eliminated the influence of stress typically present in the beginning of studies and graduation. Inclusion criteria were being aged from 18 to 26 years, being a full-time third-year student, and agreeing to sign an informed consent form. The final sample comprised 264 students (150 women, 114 men).

\section{Research tools}

First, a questionnaire developed by the authors was used to collect basic information from the participants, such as age, gender, chronic diseases, sleep length, physical activity, smoking, past psychological consultations and source of income. Then, three questionnaires were used: the Perceived Stress Scale 10 (PSS-10), an abbreviated version 
of the Coping Orientation to Problems Experienced inventory (mini-COPE inventory), and the Athens Insomnia Scale (AIS).

The PSS-10 has high psychometric properties and is widely used in research throughout the world. ${ }^{10-12}$ The questionnaire was validated and released for the first time in 1983, by American psychologist Sheldon Cohen et al. ${ }^{13}$ Juczyński \& Ogińska-Bulik translated it into Polish, ${ }^{14}$ and this version was used in our study. The PSS-10 consists of ten questions concerning frequency of thoughts and feelings regarding stressful situations that occurred during the previous month. Every question has five possible answers ranging from 0 (never) to 4 (very often). PSS-10 scores are calculated by summing up individual items and converting the results according to the appropriate formula on the sten scale. ${ }^{15}$ Scores from 1 to 4 stens correspond to a low level of stress, 5 and 6 stens indicate an intermediate level of stress, and 7 to 10 stens indicate a high level of stress. ${ }^{14}$

The mini-COPE inventory indicates which stresscoping strategies are practiced by an individual. It is one of the most frequently used questionnaires in research that evaluates this phenomenon. ${ }^{10,16,17}$ It was created in the United States in the late $1990 s,{ }^{18}$ and its Polish version was established by Juczyński \& OgińskaBulik. ${ }^{14}$ It consists of 28 statements that describe different strategies. Individuals are asked to determine how often they use a particular strategy in their life on a 4-point scale ranging from 0 (almost never) to 3 (almost always). Every statement is assigned to one of 14 stress-coping categories (planning, humor, religion, acceptance, denial, substance use, using emotional support, using instrumental support, self-blame, behavioral disengagement, active coping, positive reframing, self-distraction and venting).

Finally, the AIS consists of eight questions concerning sleep length and quality. The questionnaire was created by a group of Greek scientists in $2000^{19}$ and has been validated and used in many studies. ${ }^{20-22}$ Its Polish version was translated and adopted by Warsaw researchers. ${ }^{23}$ The first five items pertain to sleep induction, awakenings during the night, final awakening, total sleep duration, and sleep quality, while the last three refer to well-being, functional capacity, and sleepiness during the day. Each item is scored on a scale ranging from 0 to 3 . The total score is the sum of the scores. A score from 0 to 5 indicates normal sleep, from 6 to 10, minor problems with sleep, and a score of 11 and above corresponds to insomnia. ${ }^{19}$

\section{Data collection}

The data were collected in March 2017 in a group of students from seven Krakow universities. The participants independently completed questionnaires in the presence of the researcher.

\section{Statistical analysis}

Statistical analysis was performed using Statistica version 12.5. Chi-square, Student's $t$ test and Spearman's rank correlation coefficient were used. Statistical significance was set at 0.05 .

\section{Ethical considerations}

This study was approved by the bioethical commission of the Jagiellonian University Medical College (permission 122.6120.341.2016). Every participant of the study signed an informed consent form before completing the questionnaires. The study was safe and did not pose any risk to the participants.

\section{Results}

\section{Characteristics of participants}

We invited 280 students to our study and 264 of them proceeded to further analysis. Sixteen students were excluded because they had incorrectly completed the questionnaires. Participants had a mean age of $22.22 \pm 1.5$ years. Most of them were female $(150,57 \%)$. Participants represented seven universities and 13 fields of study: sociology $(20,7.5 \%)$, geophysics $(20,7.5 \%)$, forestry $(15,6 \%)$, engineering and water management $(18,7 \%)$, transportation $(22,8 \%)$, architecture $(22$, $8 \%)$, administration $(21,8 \%)$, informatics $(43,16 \%)$, design $(15,6 \%)$, tourism and recreation $(22,8 \%)$, European studies $(7,3 \%)$, physiotherapy (26, 10\%) and Italian philology (13, 5\%).

Almost half of the students $(123,46.5 \%)$ came from villages and almost $20 \%$ came from big cities (over 500 thousand inhabitants). Also, 117 (44\%) lived from money they received from their parents or had a scholarship, and 55 (21\%) earned money by themselves. The rest of the respondents had a part-time job and received financial help from their parents. Only 25 (9\%) participants suffered from chronic diseases, the most common of which were hypothyroidism (7), atopic dermatitis (5) and asthma (4).

The large majority of the sample did not smoke cigarettes $(219,83 \%)$. The remainder were smokers, using approximately one pack of cigarettes a day (1.17 packs of cigarettes on average). Also, 138 (52\%) students did not play any sport, and the other $126(48 \%)$ exercised for at least 30 minutes per day; 166 (63\%) students had a low, $72(27 \%)$ a moderate and 26 (10\%) a high level of physical activity. A low level of physical activity was defined as exercising less than twice weekly, 
and a high level as more than four times. With regard to sleep patterns, every second student $(124,47 \%)$ slept 7-8 hours per day during weekdays, 119 participants (45\%) slept 5-6 hours, 7 (3\%) 4 hours or less, and 14 (5\%) slept 9 hours or more. Most of the participants had a tendency to sleep longer on weekends - 73 (28\%) slept 9 hours or more and 124 (47\%) slept 7-8 hours.

Regarding psychological concerns, 229 (87\%) students had never visited a psychologist or psychiatrist. The most common reasons to contact a specialist from these fields were personal, undisclosed reasons (7), depression (7), and periodic examination (4).

\section{Stress level}

A high level of stress was observed in $27(10 \%)$ of the respondents, a moderate level in 87 (33\%), and a low level in 150 (57\%). In the group with a high level of stress, the large majority were women, but the differences between genders in relation to stress were not statistically significant. Students who reported that they suffered from chronic diseases were more likely to have a higher level of stress than their healthy colleagues $(p=0.006)$. Students who were cigarette smokers reported higher stress levels than non-smokers $(p=0.004)$.

No correlation was found between level of stress and physical activity, type of study or psychological consultations in the past.

\section{Stress-coping strategies}

According to the mini-COPE inventory, the most common stress-coping strategies among students from Krakow were those focusing on the problem: active coping (mean \pm standard deviation $=2.13 \pm 0.62$ ) and planning
$(2.06 \pm 0.68)$. Far fewer students used strategies such as denial $(0.68 \pm 0.74)$ and substance use $(0.56 \pm 0.78)$.

Table 1 shows how often particular stress-coping strategies were used in the study group.

There were no statistically significant differences in stress-coping strategies between students from different universities or fields of studies.

Figure 1 shows the differences in stress-coping strategies between male and female students.

Statistically, women more often than men used strategies connected with the use of emotional support $(p<0.001)$, instrumental support $(p<0.001)$, active coping $(p=0.02)$ and self-distraction $(p=0.01)$. By contrast, men more often used strategies connected with sense of humor $(p=0.007)$. There were no statistically significant differences between men and women in strategies connected with manifestation of helplessness (substance use, self-blame, behavioral disengagement).

Our study revealed many differences in stress-coping strategies between the group of students with a low or moderate level of perceived stress vs. those with a higher level. Statistically, participants with a high level of perceived stress used strategies connected with religion $(p=0.006)$ and positive reframing $(p=0.001)$ less often than people with low or moderate levels. Furthermore, in the group of students with a high level of perceived stress, strategies that manifest helplessness of the person were more common: self-blame $(p<0.001)$, behavioral disengagement $(p=0.004)$ and substance use $(p=0.006)$. Moreover, these students were more likely to use strategies connected with avoidance, such as venting $(p=0.02)$. The above findings are summarized in Figure 2.

Table 1 - The frequency with which individual stress-coping strategies were used in the study group $(n=264)$

\begin{tabular}{lcccc}
\hline Stress-coping strategies & Mean & SD & Minimum & Maximum \\
\hline Planning & 2.06 & 0.68 & 0.00 & 3.00 \\
Humor & 1.15 & 0.75 & 0.00 & 3.00 \\
Religion & 1.02 & 0.94 & 0.00 & 3.00 \\
Acceptance & 1.87 & 0.64 & 0.00 & 3.00 \\
Denial & 0.68 & 0.74 & 0.00 & 3.00 \\
Substance use & 0.56 & 0.78 & 0.00 & 3.00 \\
Use of emotional support & 1.77 & 0.80 & 0.00 & 3.00 \\
Use of instrumental support & 1.76 & 0.77 & 0.00 & 3.00 \\
Self-blame & 1.43 & 0.84 & 0.00 & 3.00 \\
Behavioral disengagement & 0.77 & 0.65 & 0.00 & 3.00 \\
Active coping & 2.13 & 0.62 & 0.00 & 3.00 \\
Positive reframing & 1.57 & 0.76 & 0.00 & 3.00 \\
Self-distraction & 1.68 & 0.68 & 0.00 & 3.00 \\
Venting & 1.51 & 0.64 & 0.00 & 3.00 \\
\hline
\end{tabular}

$\mathrm{SD}=$ standard deviation. 


\section{Insomnia}

Every second student $(124,47 \%)$ slept 7-8 hours per day during weekdays as well as on weekends. According to the AIS, 52 students (19.7\%) suffered from insomnia (score $\geq 11$ ). The mean score was $7.14 \pm 4.13$ (total ranging from 0 to 24 ). The participants of our study achieved the highest scores in the statement regarding falling asleep (question 1 in AIS). They pointed out that mostly they felt sleepy during the day (question 8). Fewer students complained of bad humor the day following a sleepless night (question 6).

A statistically significant relationship existed between insomnia and cigarette smoking $(p=0.028)$ and duration of sleep on weekends $(p=0.02)$. No correlations were found between the level of sleep disorders and gender, type of study, chronic diseases, physical activity or source of income. In Table 2 we present the level of perceived stress and the level of insomnia in relation to students' characteristics.

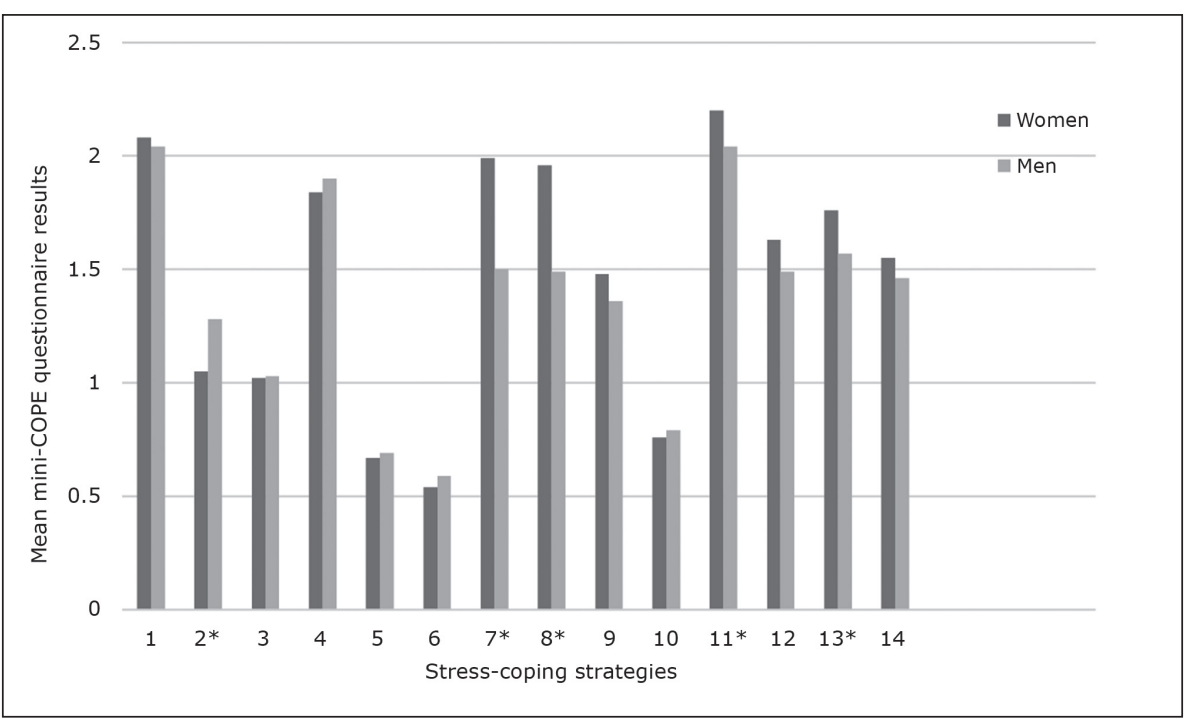

Figure 1 - Stress-coping strategies (mini-COPE, mean values) in male and female Krakow students: 1 - planning, 2 - humor, 3 religion, 4 - acceptance, 5 - denial, 6 - substance use, 7 - use of emotional support, 8 - use of instrumental support, 9 - self-blame,

10 - behavioral disengagement, 11 - active coping, 12 - positive reframing, 13 - self-distraction, 14 - venting. * $p<0.05$.

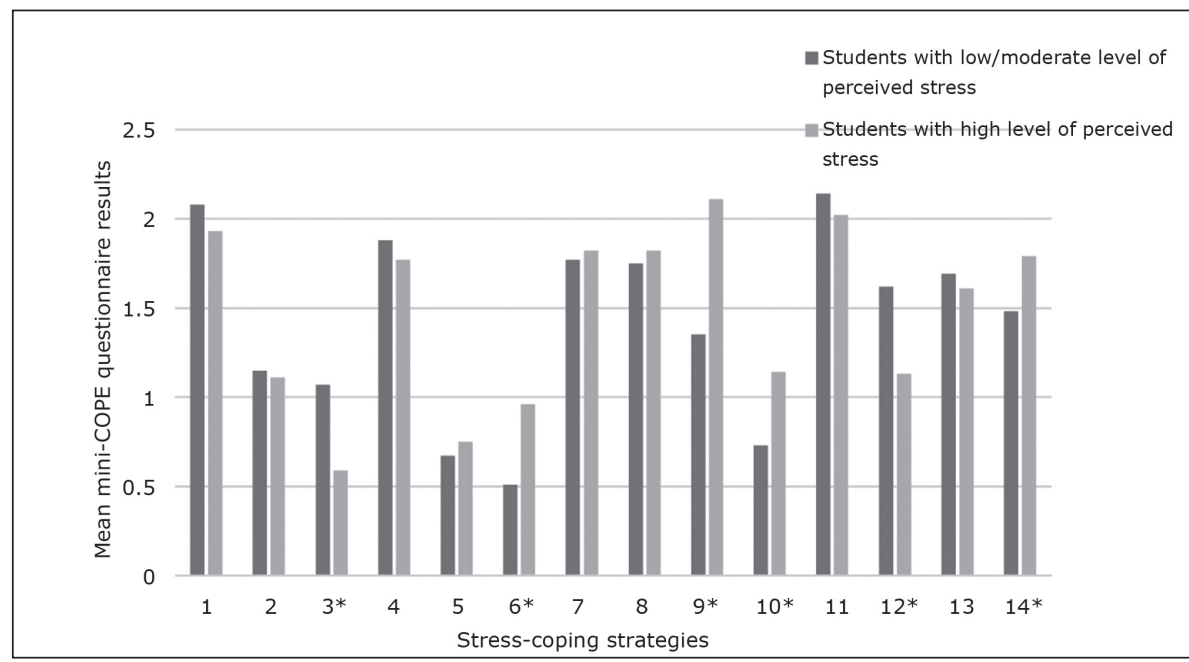

Figure 2 - Stress-coping strategies (mini-COPE, mean values) in students with low to moderate level of perceived stress and students with high level of perceived stress: 1 - planning, 2 - humor, 3 - religion, 4 -acceptance, 5 - denial, 6 - substance use, 7 - use of emotional support, 8 - use of instrumental support, 9 - self-blame, 10 - behavioral disengagement, 11 - active coping, 12 - positive reframing, 13 - self - distraction, 14 - venting. $* p<0.05$. 


\section{Relationship between insomnia and stress}

The level of insomnia correlated with the level of perceived stress $(p<0.001, r=0.44)$ (Figure 3$)$. This indicates that the more stressed a person is, the more sleep problems they are likely to have. Figure 4 shows differences in stress-coping strategies between people suffering from insomnia and healthy participants.

There were differences in stress-coping strategies between students suffering from insomnia and their healthy colleagues. In the group of students who reported sleep disorders, stress-coping strategies connected with manifestation of helplessness were statistically more common: self-blame $(p=0.04)$ and substance use $(p=0.006)$. Moreover, students who suffered from insomnia were more likely to use strategies connected with avoidance, such as denial $(p=0.03)$. By contrast, people without sleep disorders more often used a strategy connected with positive reframing of the problem $(p=0.003)$.

\section{Discussion}

\section{Main findings}

Our study showed that $10 \%$ of the examined students suffered from a high level of stress, which was more widespread in those with chronic diseases and in cigarette smokers. The most common stresscoping strategies used by the study group were active coping and planning; however, strategies were different between men and women. The study revealed that the coping strategy used by the respondents also depended on their level of stress.

Table 2 - Characteristics of the study group, level of stress and sleep disorders

\begin{tabular}{|c|c|c|c|c|c|c|c|c|}
\hline \multirow[b]{2}{*}{ Factor } & \multicolumn{4}{|c|}{ Stress level } & \multicolumn{4}{|c|}{ Sleeping disorders } \\
\hline & Low & Medium & High & $\mathbf{p}$ & No & Minor & Insomnia & $\mathbf{p}$ \\
\hline \multicolumn{9}{|l|}{ Gender } \\
\hline Female & $82(55)$ & $48(32)$ & $20(13)$ & 0.14 & $63(42)$ & $60(40)$ & $27(18)$ & 0.71 \\
\hline Male & $68(60)$ & $39(34)$ & $7(6)$ & & $47(41)$ & $42(37)$ & $25(22)$ & \\
\hline \multicolumn{9}{|l|}{ Place of residence } \\
\hline Village & $74(60)$ & $36(30)$ & $13(10)$ & 0.49 & $53(43)$ & $52(42)$ & $18(15)$ & 0.14 \\
\hline City & $76(54)$ & $51(36)$ & $14(10)$ & & $57(40)$ & $50(35)$ & $34(25)$ & \\
\hline \multicolumn{9}{|c|}{ Presence of chronic diseases } \\
\hline Yes & $10(40)$ & $8(32)$ & $7(28)$ & $0.007 *$ & $7(28)$ & $12(48)$ & $6(24)$ & 0.33 \\
\hline No & $140(59)$ & $79(33)$ & $20(8)$ & & $103(43)$ & $90(38)$ & $46(19)$ & \\
\hline \multicolumn{9}{|l|}{ Cigarette smoking } \\
\hline Yes & $16(36)$ & $24(53)$ & $5(11)$ & $0.004^{*}$ & $18(40)$ & $12(27)$ & $15(33)$ & $0.028^{+}$ \\
\hline No & $134(61)$ & $63(29)$ & $22(10)$ & & $92(42)$ & $90(41)$ & $37(17)$ & \\
\hline \multicolumn{9}{|c|}{ Hours of sleep in weekdays } \\
\hline Recommended & $81(60)$ & $42(31)$ & $12(9)$ & 0.53 & $62(46)$ & $53(39)$ & $20(15)$ & 0.1 \\
\hline Inadequate & $69(53)$ & $45(35)$ & $15(12)$ & & $48(37)$ & $49(38)$ & $32(25)$ & \\
\hline \multicolumn{9}{|c|}{ Hours of sleep on weekends } \\
\hline Recommended & $119(57)$ & $66(32)$ & $22(11)$ & 0.76 & $93(45)$ & $80(39)$ & $34(16)$ & $0.02^{+}$ \\
\hline Inadequate & $31(54)$ & $21(37)$ & $5(9)$ & & $17(30)$ & $22(38)$ & $18(32)$ & \\
\hline \multicolumn{9}{|c|}{ Regular physical activity } \\
\hline Yes & $71(56)$ & $44(35)$ & $11(9)$ & 0.66 & $57(45)$ & $43(34)$ & $26(21)$ & 0.35 \\
\hline No & $79(57)$ & $43(31)$ & $16(12)$ & & $53(38)$ & $59(43)$ & $26(19)$ & \\
\hline \multicolumn{9}{|c|}{ Psychological consultations } \\
\hline Yes & $19(54)$ & $11(32)$ & $5(14)$ & 0.7 & $14(40)$ & $11(31)$ & $10(29)$ & 0.34 \\
\hline No & $131(57)$ & $76(33)$ & $22(10)$ & & $96(42)$ & $91(40)$ & $42(18)$ & \\
\hline
\end{tabular}

Data presented as n (\%).

$* \mathrm{p}<0.01$.

$+\mathrm{p}<0.05$. 
With regard to sleep patterns, one fifth of the respondents suffered from insomnia, although most students slept for the recommended time in this age group. Moreover, the mean score obtained for the whole group was relatively high (mean value $=7.14$ points in the AIS). The level of sleep disorders was positively correlated with smoking, and there was a statistically significant relationship between level of stress and insomnia.

\section{Comparisons with other studies}

Most of the published studies that assess the level of stress using the PSS-10 involved students of specific subjects and did not show a cross-sectional image of student society. A study performed in Poland among nursing students showed that the majority of them had a high stress level. ${ }^{24} \mathrm{~A}$ Malaysian study involving dentistry students showed that the mean score in PSS-10 questionnaire was $21.2,{ }^{25}$ whereas a study among students from the Department of Science at the University of Salerno, Italy, revealed that the mean score of PSS-10 was 32.2. ${ }^{26}$ Our study stands in contrast to the Polish and Italian studies mentioned above; however, the results of the Malaysian study are comparable. In our research, the majority of the

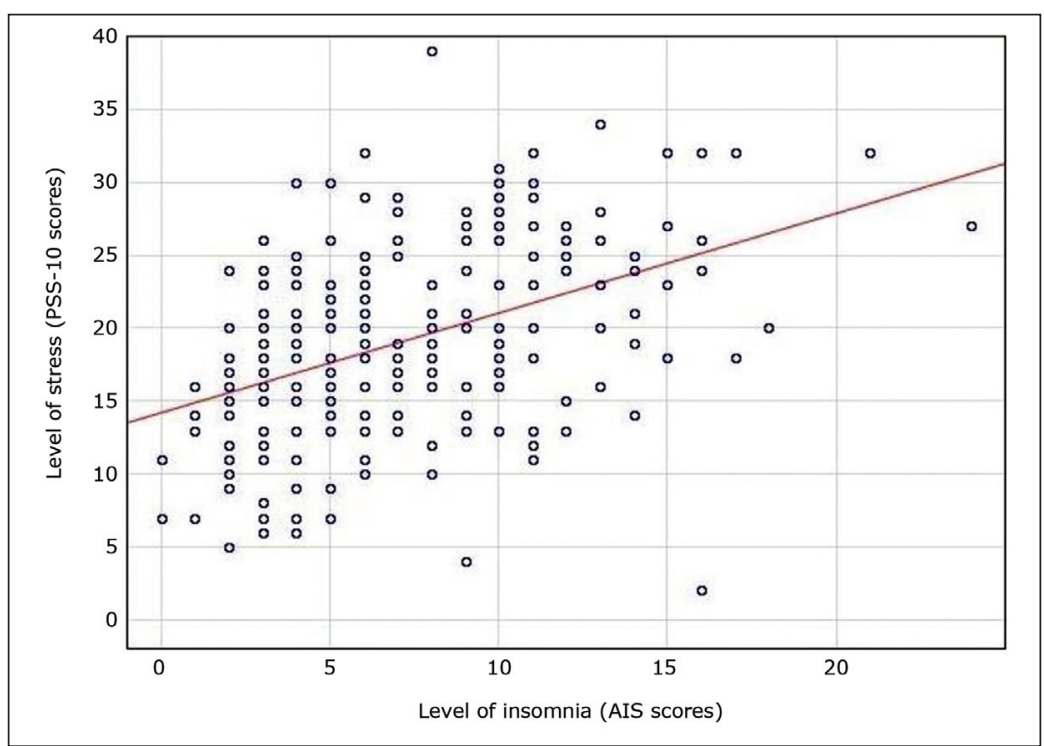

Figure 3 - Correlation between insomnia and perceived stress. AIS = Athens Insomnia Scale; PSS-10 = Perceived Stress Scale 10.

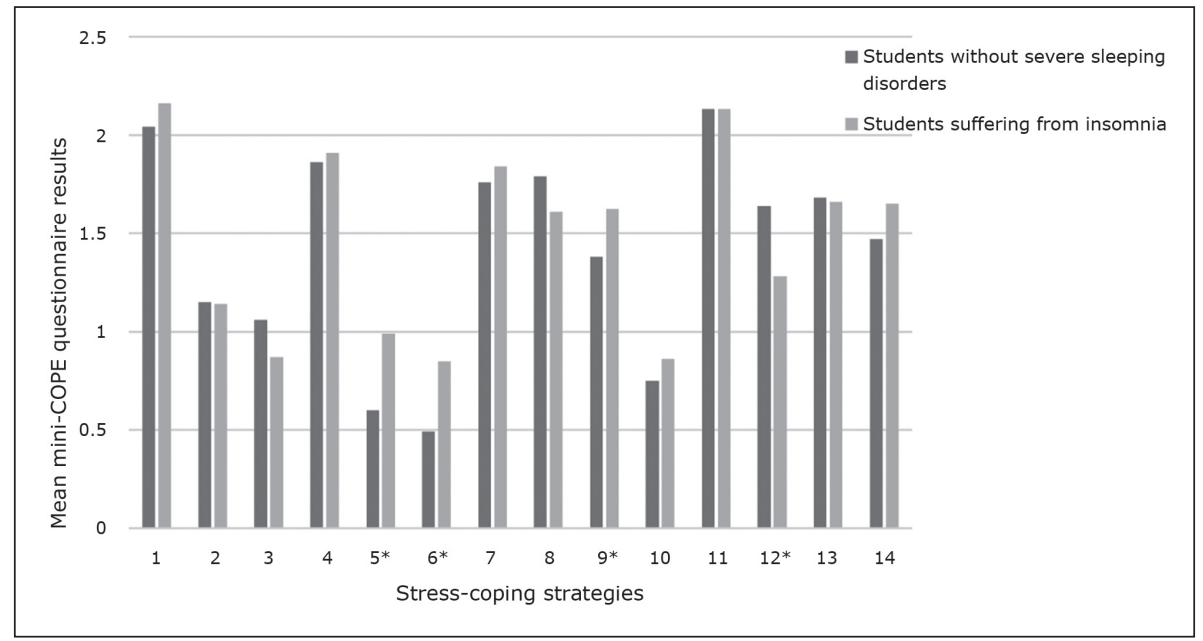

Figure 4 - Stress-coping strategies (mini-COPE, mean values) in students suffering from insomnia and students without severe sleep disorders: 1 - planning, 2 - humor, 3 - religion, 4 - acceptance, 5 - denial, 6 - substance use, 7 - use of emotional support, 8 - use of instrumental support, 9 - self-blame, 10 - behavioral disengagement, 11 - active coping, 12 - positive reframing, 13 - self-distraction, 14 - venting. $* p<0.05$. 
students had a moderate level of stress; additionally, the mean score of the PSS-10 was 19.04.

There are many studies assessing levels of insomnia among students throughout the world, based on several insomnia scales, e.g., the AIS, the Pittsburgh Sleep Quality Index (PSQI), and so on. A major cross-sectional study conducted in Ethiopia revealed that 55.8\% $(1,424)$ of the respondents had poor sleep quality. ${ }^{27}$ Also, 33\% of Saudi-Arabian medical students revealed insomnia symptoms during their clinical years. ${ }^{28}$ A recent crosssectional study performed with the Polish population (age: 18-79) revealed that, in the youngest group (age: 1839 ), self-reported insomnia occurred in $44.3 \%$ of women and $32.1 \%$ of men. ${ }^{9}$ This showed that the intensification of insomnia was much more severe than in our study, where the problem was found in $19.7 \%$ of the students. A systematic review published in 2015 revealed that the prevalence of insomnia in university students was significantly high $(18.5 \%)$, and these results coincide with ours. ${ }^{29}$ Finally, the correlation between insomnia and level of stress that was found in our study was also revealed in all the above-mentioned studies.

Moving on to the stress-coping strategies in our study, males used strategies connected with sense of humor, whereas women relied on strategies connected with the use of emotional and instrumental support. A Spanish study involving university students also showed gender-related differences. ${ }^{6}$ A study assessing the correlation between stress and coping strategies among college students in the USA showed that higher interpersonal stress caused greater use of disengagement coping strategies. ${ }^{30}$ The results of our study are similar: respondents with a high level of stress revealed self-blame, behavioral disengagement and substance use more often than lessstressed individuals. We found no study assessing the correlation between insomnia and stress-coping strategies among students while writing this article.

\section{Strengths and limitations}

One of the most important strengths of this study is that it shows a representation of students from all public universities in the city of Krakow. This is the first study of this kind in Poland involving such a diverse group of students. Transparency of inclusion and exclusion criteria as well as the use of validated Polish versions of the questionnaires are also strong points in the research. Moreover, our study is unique, because never before has anyone assessed correlations between insomnia and stress-coping strategies.

However, there are some limitations to our study that need to be taken into account. We used a self-reported questionnaire to gather data, which is prone to response (e.g. social desirability, extreme response) and recall (e.g. inaccurate memory) biases. In our questionnaire, there were no questions about alcohol consumption or drug use, and this may be considered as another limitation. Moreover, the fact that the study was performed in only one city does not allow us to generalize the findings to the entire student population in Poland. Additionally, the characteristics of the participants from each university may have had an impact on the results (less vs. more stressful fields of studies).

\section{Interpretation of study findings and implications for practice and research}

According to our results, the level of stress in most of the students reached a moderate level. However, some groups require further observation. Due to the fact that respondents suffering from chronic diseases are more stressed than their healthy counterparts, we believe that, during the treatment of chronic illnesses, psychological condition should also be taken into account.

Coping strategies used by students with a high level of stress are the fields that need to be addressed. Positive ways of coping with stress should be introduced to those students by psychologists or family physicians.

Insomnia, which occurred in almost $20 \%$ of the respondents, was strongly connected with stress. We believe that, during medical consultations of students for different reasons, family physicians should ask about any sleep disorders and administer proper procedures.

In our opinion, only complex actions, including psychological and medical support, can lead to a decrease in the level of stress and insomnia and improve stresscoping strategies in the younger population. Perhaps initiating free psychological help at universities and providing information on how to deal with stress might be ways to improve the quality of life of young people.

\section{Conclusions}

1. The level of stress in most of the Krakow students participating in the study stands at a moderate level, however one tenth of the students present a high level of stress. Factors that correlate with level of stress are occurrence of chronic diseases and smoking.

2. Stress-coping strategies differ according to gender, level of stress and occurrence of insomnia. Polish students generally use positive stress-coping strategies such as active coping and planning, both of which are types of strategy focusing on the problem.

3. Even though insomnia is generally considered to be a problem encountered by older people, $20 \%$ 
of the students achieved high scores for sleep disorders.

4. There was a strong positive correlation between level of insomnia and level of stress.

5. It is very important to pay close attention to the aforementioned phenomena to introduce changes in the care of young people and improve quality of life. General practitioners, especially, should be aware of the potential problems caused by stress and insomnia among students.

\section{Disclosure}

Tomasz Tomasik has received personal fees from AbbVie Polska Sp. z o.o., Valeant Polska sp. z o.o. sp. j., Krka Polska Sp z o.o., and Eli Lilly Polska Sp. z o.o. No other conflicts of interest declared concerning the publication of this article.

\section{References}

1. Simandan D. On how much one can take: relocating exploitation and exclusion within the broader framework of allostatic load theory. Health Place. 2010;16:1291-3.

2. Kopp MS, Skrabski A, Székely A, Stauder A, Williams R. Chronic stress and social changes: socioeconomic determination of chronic stress. Ann NY Acad Sci. 2007;1113:325-38.

3. Rosiek A, Rosiek-Kryszewska A, Leksowski $Ł$, Leksowski K. Chronic stress and suicidal thinking among medical students. Int J Environ Res Public Health. 2016;13:212.

4. Uszyński M. Stres i antystres - patomechanizm i skutki zdrowotne. Wrocław: MedPharm Polska; 2009. p. 11, 56. Polish.

5. Ryff CD. Happiness is everything, or is it? Explorations on the meaning of psychological well-being. J Pers Soc Psychol. 1989; 57:1069-81.

6. Freire C, Ferradás MD, Valle A, Núñez JC, Vallejo G. Profiles of psychological well-being and coping strategies among university students. Front Psychol. 2016;7:1554.

7. Bjorvatn B, Meland E, Flo E, Mildestvedt T. High prevalence of insomnia and hypnotic use in patients visiting their general practitioner. Fam Pract. 2017;34:20-4.

8. Bailly D, Bailly-Lambin I, Querleu D, Beuscart R, Collinet C. Sleep in adolescents and its disorders. A survey in schools. L'Encephale. 2004;30:352-9. French.

9. Nowicki Z, Grabowski K, Cubała WJ, Nowicka-Sauer K, Zdrojewski $\mathrm{T}$, Rutkowski M, et al. Prevalence of self-reported insomnia in general population of Poland. Psychiatr Pol. 2016;50:165-73.

10. Urbańska K, Żelazko A, Domagalska J, Nowak P. Comparison of exposure to stress and analysis of ways of coping with stress among freight transport and public transport drivers. Med Pr. 2016;67:455-66. Polish.

11. Al Sunni A, Latif R. Effects of chocolate intake on perceived stress; a controlled clinical study. Int J Health Sci. 2014;8:393-401.
12. Leon KA, Hyre AD, Ompad D, Desalvo KB, Muntner P. Perceived stress among a workforce 6 months following hurricane Katrina. Soc Psychiatry Psychiatr Epidemiol. 2007;42:1005-11.

13. Cohen S, Kamarck T, Mermelstein S. A global measure of perceived stress. J Health Soc Behav. 1983;24:385-96.

14. Juczyński Z, Ogińska-Bulik N. Narzędzia pomiaru stresu i radzenia sobie ze stresem. Warszawa: Pracownia Testów Psychologicznych; 2009. Polish.

15. Hill RJ, McKernan LC, Wang L, Coronado RA. Changes in psychosocial well-being after mindfulness-based stress reduction: a prospective cohort study. J Man Manip Ther. 2017;25:128-36.

16. Ribeyre L, Spitz E, Frère J, Gauchard G, Parietti-Winkler C. Correlations between postural control and psychological factors in vestibular schwannoma patients. J Vestib Res. 2016;26:387-94.

17. Hagan TL, Fishbein JN, Nipp RD, Jacobs JM, Traeger L, Irwin KE, et al. Coping in patients with incurable lung and gastrointestina cancers: a validation study of the brief COPE. J Pain Symptom Manage. 2016;53:131-8.

18. Carver CS. You want to measure coping but your protocol's too long: Consider the Brief COPE. Int J Behav Med. 1997;4:92-100.

19. Soldatos CR, Dikeos DG, Paparrigopoulos TJ. Athens Insomnia Scale: validation of an instrument based on ICD-10 criteria. J Psychosom Res. 2000;48:555-60.

20. Yen $\mathrm{CF}$, King BH, Chang YP. Factor structure of the Athens Insomnia Scale and its associations with demographic characteristics and depression in adolescents. J Sleep Res. 2010;19:12-8.

21. Siomos KE, Braimiotis D, Floros GD, Dafoulis $V$, Angelopoulos NV. Insomnia symptoms among Greek adolescent students with excessive computer use. Hippokratia. 2010;14:203-7.

22. Miyake M, Kirisako T, Kokubo T, Miura Y, Morishita K, Okamura $H$, et al. Randomised controlled trial of the effects of L-ornithine on stress markers and sleep quality in healthy workers. Nutr J. 2014;13:53.

23. Fornal-Pawłowska M, Wołyńczyk-Gmaj D, Szelenberger W. Walidacja Ateńskiej Skali Bezsenności. Psychiatr Pol. 2011;45:21121. Polish.

24. Bodys-Cupak I, Majda A, Zalewska-Puchała J, Kamińska A. The impact of a sense of self-efficacy on the level of stress and the ways of coping with difficult situations in Polish nursing students. Nurse Educ Today. 2016;45:102-7.

25. Saddki N, Sukerman N, Mohamad D. Association between emotional intelligence and perceived stress in undergraduate dental students. Malays J Med Sci. 2017;24:59-68.

26. Cavallo P, Carpinelli L, Savarese G. Perceived stress and bruxism in university students. BMC Research Notes. 2016;9:514.

27. Lemma S, Gelaye B, Berhane Y, Worku A, Williams MA. Sleep quality and its psychological correlates among university students in Ethiopia: a cross-sectional study. BMC Psychiatry. 2012;12:237.

28. Alsaggaf MA, Wali So, Merdad RA, Merdad LA. Sleep quantity, quality, and insomnia symptoms of medical students during clinical years. Relationship with stress and academic performance. Saudi Med J. 2016;37:173-82.

29. Jiang $X L$, Zheng $X Y$, Yang J, Ye CP, Chen $Y Y$, Zhang $Z G$, et al. Systematic review of studies on the prevalence of insomnia in university students. Public Health. 2015;129:1579-84.

30. Coiro MJ, Bettis AH, Compas BE. College students coping with interpersonal stress: Examining a control-based model of coping. J Am Coll Health. 2017;65:177-86.

\section{Correspondence:}

Anna Średniawa

Department of Family Medicine, Jagiellonian University Medical College

Bocheńska 4

31-061 - Cracow - Poland

Tel.: +48 (12) 4305593

E-mail: annasredniawa@gmail.com 